\title{
IMPLEMENTASI METODE PEMBOBOTAN BERBASIS ATURAN DAN METODE PROFILE MATCHING PADA SISTEM PAKAR MEDIS UNTUK PREDIKSI RISIKO HIPERTENSI
}

\author{
Agus Wantoro ${ }^{1)}$, Admi Syarif ${ }^{2)}$, Khairun Nisa Berawi ${ }^{3)}$, Kurnia Muludi ${ }^{4)}$, Sri Ratna Sulistiyanti ${ }^{\text {5) }}$, Sutyarso ${ }^{6)}$, \\ ${ }^{I}$ Doktor MIPA, Fakultas Matematika dan Ilmu Pengetahuan Alam, Universitas Lampung \\ ${ }^{2,4}$ Ilmu Komputer, Fakultas Matematika dan Ilmu Pengetahuan Alam, Universitas Lampung \\ ${ }^{3}$ Kesehatan Masyarakat, Fakultas Kedokteran, Universitas Lampung \\ ${ }^{5}$ Teknik Elektro, Fakultas Teknik, Universitas Lampung \\ ${ }^{2}$ Biologi, Fakultas Matematika dan Ilmu Pengetahuan Alam, Universitas Lampung \\ ${ }^{1}$ Jl. Jl.Prof.Dr.Sumantri Brojonegoro No.1, Gedung Meneng, Bandar Lampung \\ Email: ${ }^{1}$ aguswantoro@teknokrat.ac.id, ${ }^{2}$ admi.syarif@fmipa.unila.ac.id, ${ }^{3}$ khairun.nisa@fk.unila.ac.id, \\ ${ }^{4}$ kmuludi@fmipa.unila.ac.id, ${ }^{5}$ sr_sulistiyanti@eng.unila.ac.id, ${ }^{6}$ sutyarso.sty@gmail.com
}

\begin{abstract}
Cardiovascular is a disease that often causes death. One of the cardiovascular diseases that often cause death is the risk of Hipertensi. The highest risk factors for premature death and disability in the world are caused by smoking habits, high systolic blood pressure, and increased blood sugar levels. This death factor is because people with Hipertensi generally do not experience any symptoms until their blood pressure is too high which can cause death. Efforts that can be made are by utilizing information technology in the form of a medical expert system to Kelasify the risk of Hipertensi. This study aims to develop a medical expert system in a different way using rule-based weighting methods and profile matching. The weighting method is used to determine the risk weight based on patient variables, while the profile matching method is used to calculate the risk Kelasification based on the core factor and secondary factor variables on the risk of Hipertensi. System evaluation is carried out by comparing asset data taken from the Pima Indian Hipertensi Data (NHANES) with results from the system. The results of the comparison show that the accuracy of the proposed system is $96.67 \%$. The proposed system is also compared with other Kelasification methods such as decision tree, Random Tree, Decision Stump, KNN, Nä̈ve BaYa, Deep Learning, and Rule Induction. Based on the comparison results, the proposed system has a better level of accuracy, therefore the system developed can be used to Kelasify risks for other types of diseases.
\end{abstract}

Keywords: Hipertensi Risk, Rule-Based Weighting, Profile Matching, Expert System

\begin{abstract}
Abstrak
Kardiovaskular merupakan penyakit yang sering menyebabkan kematian. Salah satu penyakit kardiovaskular yang sering menyebabkan kematian adalah risiko hipertensi. Faktor risiko kematian dini tertinggi di dunia disebabkan oleh kebiasaan merokok, tekanan darah sistolik yang tinggi, dan peningkatan kadar gula darah. Faktor kematian ini karena penderita risiko hipertensi umumnya tidak mengalami gejala apapun hingga tekanan darah yang tinggi akhirnya menyebabkan kematian. Upaya yang dapat dilakukan adalah dengan memanfaatkan teknologi informasi berupa sistem pakar medis untuk mengklasifikasikan risiko hipertensi.Penelitian ini mengembangkan sistem pakar medis dengan cara yang berbeda menggunakan metode pembobotan berbasis aturan dan metode profil matching. Metode pembobotan digunakan untuk menentukan bobot risiko berdasarkan variabel pasien, sedangkan metode profil matching digunakan untuk menghitung klasifikasi risiko berdasarkan variabel core factor dan secondary factor terhadap risiko hipertensi. Evaluasi sistem dilakukan dengan membandingkan data aset yang diambil dari Pima Indian Hipertensi Data (NHANES) dengan system usulan. Hasil perbandingan menunjukkan bahwa akurasi sistem usulan sebesar $96.67 \%$. Sistem usulan juga dibandingkan dengan metode klasifikasi lain seperti Decision tree, Random Tree, Decision Stump, KNN, Naïve Ba Ya, Deep Learning, dan Rule Induction. Berdasarkan hasil perbandingan, sistem usulan memiliki tingkat akurasi yang lebih baik, sehingga sistem pakar dapat digunakan untuk mengklasifikasikan risiko untuk jenis penyakit lainnya.
\end{abstract}

\section{Kata Kunci: Risiko hipertensi, Pembobotan Berbasis Aturan, Profile Matching, Sistem Pakar}

\section{Pendahuluan}

Kardiovaskular merupakan penyakit yang menyebabkan kematian. Hal ini disebabkan gaya hidup modern yang serba instan dan kurang olahraga. Salah satu penyakit kardiovaskular yang sering menyebabkan kematian adalah hipertensi [2]. Hipertensi atau tekanan darah tinggi adalah kondisi ketika tekanan darah mencapai 140/80 mmHg. Hipertensi memiliki 2 (dua) jenis yaitu primer dan sekunder[3]. Hipertensi primer belum diketahui penyebabnya secara pasti, sedangkan hipertensi sekunder dapat terjadi karena penyakit ginjal, merokok, 
dan alkoholisme [4]. Hipertensi masih menjadi penyumbang kematian dini terbesar di dunia. Hipertensi memiliki istilah silent killer atau penyakit yang membunuh secara diam-diam [5]. Data dari pelayanan BPJS untuk pasien hipertensi mengungkapkan biaya yang dikeluarkan untuk berobat sebesar Rp. 3 triliun/tahun

Faktor risiko kematian dini tertinggi di dunia disebabkan oleh beberapa hal seperti kebiasaan merokok, tekanan darah sistolik yang tinggi, dan peningkatan kadar gula darah. Faktor kematian ini karena penderita hipertensi umumnya tidak mengalami gejala apapun sampai tekanan darahnya terlalu tinggi dan dapat menyebabkan kematian. Pemeriksaan tekanan darah secara mandiri dan rutin atau datang langsung ke dokter untuk mengetahui risiko hipertensi merupakan hal yang penting untuk dilakukan. Pemeriksaan untuk mengidentifikasi risiko hipertensi memerlukan pengetahuan dan ketelitian dari dokter ahli, namun tidak semua rumah sakit dan klinik kesehatan memiliki dokter ahli untuk mendiagnosis risiko hipertensi. [7]. Salah satu upaya yang dapat dilakukan dengan memanfaatkan teknologi berupa sistem pakar medis yang dapat mengklasifikasikan risiko hipertensi berdasarkan kondisi pasien. Sistem yang dikembangkan dapat membantu dokter dalam mendiagnosis risiko hipertensi dengan lebih cepat dan akurat, sehingga risiko pasien hipertensi dapat didiagnosis secara dini dan segera mendapatkan pengobatan. Beberapa penelitian tentang diagnosis risiko hipertensi telah dilakukan yang ditunjukkan pada Tabel 1 menggunakan berbagai algoritma seperti fuzzy, algoritma genetika, pohon keputusan, c4.5, machine learning, dan Support Vector Machine (SVM). Namun penerapan metode pembobotan yang dikombinasikan dengan metode Profile Matching untuk diagnosis risiko hipertensi belum ditemukan.

Penelitian ini bertujuan untuk mengembangkan sistem pakar medis menggunakan metode rule-based weighting dan profile matching. Metode rule-based weighting digunakan untuk menentukan bobot risiko berdasarkan variabel pasien, sedangkan metode profile matching digunakan untuk menghitung nilai variabel core factor dan secondary factor terhadap risiko hipertensi sehingga pasien dapat diklasifikasikan memiliki risiko hipertensi. atau tidak.

\section{Penelitian Terkait}

Banyak penelitian yang menerapkan algoritma kecerdasan buatan untuk mendeteksi risiko hipertensi telah dilakukan dengan menggunakan berbagai metode dan algoritma. Penelitian terkait diagnosis risiko hipertensi dirangkum dan disajikan pada Tabel 1

Tabel 1. Penelitian kecerdasan buatan tentang diagnosis risiko hipertensi

\begin{tabular}{|c|c|c|c|c|}
\hline No & Penulis & Metode & Variabel & Tujuan \\
\hline 1 & $\begin{array}{l}\text { Abdullah, Zakaria, } \\
\text { and } \\
\text { Mohammad,2011 } \\
{[8]}\end{array}$ & $\begin{array}{l}\text { Fuzzy } \\
\text { Mamdani }\end{array}$ & $\begin{array}{l}\text { Jenis kelamin, usia, BMI, tekanan } \\
\text { darah, detak jantung }\end{array}$ & Diagnosis risiko hipertensi \\
\hline 2 & $\begin{array}{l}\text { Djam and Kimbi, } \\
2011[9]\end{array}$ & $\begin{array}{l}\text { Fuzzy } \\
\text { Mamdani }\end{array}$ & $\begin{array}{l}\text { Tekanan darah sistolik, tekanan } \\
\text { darah diastolik, usia, BMI }\end{array}$ & Diagnosis risiko hipertensi \\
\hline 3 & $\begin{array}{l}\text { Das, Ghosh, and } \\
\text { Kar, } 2013 \text { [10] }\end{array}$ & $\begin{array}{l}\text { Fuzzy } \\
\text { Mamdani }\end{array}$ & $\begin{array}{l}\text { Jenis Kelamin, Usia, BMI, tekanan } \\
\text { darah, detak jantung }\end{array}$ & Diagnosis risiko hipertensi \\
\hline 4 & $\begin{array}{l}\text { Srivastava et al, } \\
2013[11]\end{array}$ & Fuzzy Sugeno & $\begin{array}{l}\text { Usia, BMI, Detak Jantung, } \\
\text { Kolesterol, Merokok }\end{array}$ & Klasifikasi risiko hipertensi \\
\hline 5 & $\begin{array}{l}\text { Kaur and Bhardwaj, } \\
2014 \text { [12] }\end{array}$ & $\begin{array}{l}\text { Genetic } \\
\text { Algorithm, } \\
\text { and neuro- } \\
\text { fuzzy }\end{array}$ & $\begin{array}{l}\text { Darah Sistolik, Darah Diastolik, } \\
\text { IMT, Denyut Jantung, Kolesterol, } \\
\text { Glukosa, Urea Darah, Kreatinin, } \\
\text { Asam Urat }\end{array}$ & Diagnosis risiko hipertensi \\
\hline 6 & $\begin{array}{l}\text { Kaur and Kaur, } \\
2015[13]\end{array}$ & $\begin{array}{l}\text { Fuzzy } \\
\text { Mamdani }\end{array}$ & $\begin{array}{l}\text { Usia, BMI, Tekanan Darah, Denyut } \\
\text { Jantung, Jenis Kelamin, Kadar Gula, } \\
\text { Aktivitas Fisik }\end{array}$ & Diagnosis risiko hipertensi \\
\hline 7 & $\begin{array}{l}\text { Abrishami and } \\
\text { Tabatabaee, } 2015 \\
{[14]}\end{array}$ & $\begin{array}{l}\text { Fuzzy } \\
\text { Mamdani }\end{array}$ & BMI dan Tekanan Darah Sistolik & Diagnosis risiko hipertensi \\
\hline 8 & $\begin{array}{l}\text { Guzmán, Melin and } \\
\text { Prado-Arechiga, } \\
2017 \text { [15] }\end{array}$ & $\begin{array}{l}\text { Fuzzy } \\
\text { Mamdani }\end{array}$ & Tekanan darah sistolik dan diastolik & Diagnosis risiko hipertensi \\
\hline 9 & Adebayo, 2017 [16] & $\begin{array}{l}\text { Decision } \\
\text { Trees (ID3 } \\
\text { dan C4.5) }\end{array}$ & $\begin{array}{ll}\text { Alkohol, } \quad \text { Olahraga, } & \text { Status } \\
\text { Perkawinan; Jenis kelamin } & \end{array}$ & Klasifikasi risiko hipertensi \\
\hline 10 & $\begin{array}{l}\text { Guzmán, Melin and } \\
\text { Prado- } \\
\text { Arechiga,2018 [17] }\end{array}$ & $\begin{array}{l}\text { Fuzzy and } \\
\text { Genetic } \\
\text { Algorithm }\end{array}$ & Tekanan darah sistolik dan diastolik & Diagnosis risiko hipertensi \\
\hline
\end{tabular}




\begin{tabular}{|c|c|c|c|c|}
\hline 11 & Jibril, 2018 [18] & Fuzzy & $\begin{array}{l}\text { BMI, Usia, Kehamilan, Status } \\
\text { Perkawinan }\end{array}$ & Diagnosis hipertensi \\
\hline 12 & $\begin{array}{l}\text { Miramontes et al. } \\
2018 \text { [19] }\end{array}$ & $\begin{array}{l}\text { Fuzzy } \\
\text { Mamdani }\end{array}$ & Umur, Nafas & Diagnosis risiko hipertensi \\
\hline 13 & Jie et al.2018 [20] & $\begin{array}{l}\text { Ontology } \\
\text { expert system, } \\
\text { Web Semantic }\end{array}$ & $\begin{array}{l}\text { Riwayat hipertensi dan tekanan } \\
\text { darah }\end{array}$ & Diagnosis hipertensi \\
\hline 14 & $\begin{array}{l}\text { Melin, Miramontes } \\
\text { and Prado- } \\
\text { Arechiga, 2018 [21] }\end{array}$ & $\begin{array}{l}\text { Neural } \\
\text { networks and } \\
\text { fuzzy systems }\end{array}$ & $\begin{array}{l}\text { Tekanan darah sistolik, diastolik, } \\
\text { Usia, Nafas, Merokok }\end{array}$ & Klasifikasi risiko hipertensi \\
\hline 15 & $\begin{array}{l}\text { Melin and Prado- } \\
\text { Arechiga, } 2018 \text { [22] }\end{array}$ & $\begin{array}{l}\text { Fuzzy } \\
\text { Mamdani }\end{array}$ & Tekanan darah sistolik dan diastolik & Klasifikasi risiko hipertensi \\
\hline 16 & $\begin{array}{l}\text { Hossain, Fatema- } \\
\text { Tuj-Johora and } \\
\text { Andersson, } 2019 \\
{[23]}\end{array}$ & Rule-based & $\begin{array}{l}\text { BMI, Tekanan Darah, Denyut } \\
\text { Jantung, Sakit Kepala, Nyeri dada, } \\
\text { Kelelahan, Sesak napas, masalah } \\
\text { penglihatan, gejala }\end{array}$ & Diagnosis hipertensi \\
\hline 17 & $\begin{array}{l}\text { Elshawi, Al-Mallah } \\
\text { and Sakr, 2019 [24] }\end{array}$ & $\begin{array}{l}\text { Machine } \\
\text { learning }\end{array}$ & $\begin{array}{l}\text { Usia, Tekanan Darah, Riwayat } \\
\text { Hiperlipidemia, Riwayat Diabetes, } \\
\text { Ras }\end{array}$ & Prediksi hipertensi \\
\hline 18 & $\begin{array}{l}\text { Tengnah, Sooklall } \\
\text { and Nagowah, } 2019 \\
{[25]}\end{array}$ & $\begin{array}{l}\text { Machine } \\
\text { learning }\end{array}$ & $\begin{array}{l}\text { Usia, Jenis Kelamin, Kehamilan, } \\
\text { IMT, Riwayat Hipertensi, Merokok, } \\
\text { Konsumsi Alkohol, Tingkat Stres, } \\
\text { Konsumsi Garam, Tekanan Darah }\end{array}$ & Diagnosis hipertensi \\
\hline 19 & $\begin{array}{l}\text { Chang et al., } 2019 \\
\text { [26] }\end{array}$ & $\begin{array}{l}\text { Machine- } \\
\text { learning } \\
\text { XGBoost }\end{array}$ & $\begin{array}{l}\text { Jenis Kelamin, Usia, Tinggi Badan, } \\
\text { Berat Badan, BMI }\end{array}$ & Diagnosis hipertensi \\
\hline 20 & $\begin{array}{l}\text { Shiraz H.E, } 2019 \\
\text { [27] }\end{array}$ & Fuzzy & $\begin{array}{l}\text { Tekanan darah sistolik, Diastolik, } \\
\text { low-density lipoprotein, high- } \\
\text { density lipoprotein, Usia, BMI }\end{array}$ & Klasifikasi risiko hipertensi \\
\hline 21 & $\begin{array}{l}\text { Nour and Polat, } \\
2020[28]\end{array}$ & $\begin{array}{l}\text { Machine } \\
\text { learning }\end{array}$ & $\begin{array}{l}\text { Usia, Jenis Kelamin, Tinggi Badan, } \\
\text { Berat Badan, Tekanan Darah } \\
\text { Sistolik, Diastolik, Denyut Jantung, } \\
\text { IMT }\end{array}$ & Klasifikasi risiko hipertensi \\
\hline 22 & $\begin{array}{l}\text { Ambika, } \\
\text { Raghuraman and } \\
\text { SaiRamesh, } 2020 \\
\text { [29] }\end{array}$ & $\begin{array}{l}\text { Support vector } \\
\text { machine } \\
(\mathrm{SVM})\end{array}$ & $\begin{array}{l}\text { Merokok, Konsumsi Alkohol, Diet } \\
\text { Tidak Sehat HH, Aktivitas Fisik, } \\
\text { Tekanan Darah Tinggi, Gula Darah } \\
\text { Naik, Obesitas }\end{array}$ & $\begin{array}{l}\text { Memprediksi dan mencegah } \\
\text { hipertensi }\end{array}$ \\
\hline 23 & $\begin{array}{l}\text { Chatrati et al., } 2020 \\
{[30]}\end{array}$ & $\begin{array}{l}\text { Support vector } \\
\text { machine } \\
\text { (SVM) }\end{array}$ & Tekanan darah sistolik dan diastolik & Memprediksi hipertensi \\
\hline 24 & $\begin{array}{l}\text { Lopez-Martínez, } \\
2020[31]\end{array}$ & $\begin{array}{l}\text { Artificial } \\
\text { neural } \\
\text { network }\end{array}$ & $\begin{array}{l}\text { Usia, jenis kelamin, etnis, BMI, } \\
\text { riwayat merokok, penyakit ginjal, } \\
\text { diabetes }\end{array}$ & $\begin{array}{l}\text { Memprediksi dan mencegah } \\
\text { hipertensi }\end{array}$ \\
\hline 25 & Penelitian ini & $\begin{array}{l}\text { Profile } \\
\text { Matching }\end{array}$ & $\begin{array}{l}\text { Usia, jenis kelamin, etnis, BMI, } \\
\text { asap, ginjal, diabetes }\end{array}$ & Klasifikasi risiko hipertensi \\
\hline
\end{tabular}

Abdullah, Zakaria, dan Mohammad [8] menggunakan fuzzy Mamdani untuk mendiagnosis risiko hipertensi. Hasil diagnosis risiko hipertensi ditampilkan dengan nilai persentase. Djam dan Kimbi [9] menggunakan variabel sistolik, diastolik, umur, dan BUMI dengan logika fuzzy dan FIS Mamdani untuk mengklasifikasikan 3 (tiga) risiko hipertensi yaitu ringan, sedang dan berat. Das, Ghosh, dan Kar [10] Das menggunakan neuro-fuzzy untuk mendiagnosis risiko hipertensi dengan output persentase risiko. Srivastava et al [11] membangun sistem pendukung keputusan untuk klasifikasi hipertensi. Klasifikasi tersebut adalah sangat rendah, rendah, sedang, tinggi, dan sangat tinggi. Kaur dan Bhardwaj [12] menggunakan metode fuzzy neurogenetic untuk diagnosis hipertensi memiliki tingkat akurasi 86\%. Kaur dan Kaur [13] mengembangkan sistem pakar untuk diagnosis hipertensi dalam nilai persentase. Abrishami, dan Tabatabaee [14] menggunakan kombinasi algoritma fuzzy dan jaringan saraf multi-layer untuk diagnosis hipertensi. Adebayo [16] menggunakan algoritma ID3 untuk mengklasifikasikan risiko hipertensi. Model yang diusulkan memperoleh nilai akurasi sebesar 86,36\%. Guzmán, Melin, dan Prado-Arechiga [17] menggunakan algoritma genetika fuzzy untuk klasifikasi tekanan darah. Outputnya berupa tingkat tekanan darah. Jibril [18] membangun sistem pakar medis untuk deteksi dini risiko hipertensi menggunakan algoritma berbasis pengetahuan. Sistem yang dikembangkan memiliki tingkat akurasi dan kecepatan yang tinggi dalam 
mendiagnosis pasien. Miramontes et al [19] menerapkan logika fuzzy untuk diagnosis risiko hipertensi dengan nilai akurasi sistem 95\%. Jie dkk. [20] mengembangkan sistem pakar berbasis ontologi untuk diagnosis dan pengobatan hipertensi. Sistem yang dikembangkan dapat meningkatkan efisiensi diagnosis. Melin, Miramontes, dan Prado-Arechiga [21] melakukan penelitian menggunakan jaringan syaraf tiruan yang dikombinasikan dengan fuzzy untuk klasifikasi tekanan darah dan diagnosis risiko hipertensi. Berdasarkan penggunaan beberapa modul, sistem memiliki tingkat akurasi rata-rata 97,81\%. Hossain, Fatema-Tuj-Johora, dan Andersson [23] Budi mengembangkan sistem pakar berbasis aturan keyakinan untuk menilai hipertensi di bawah ketidakpastian. Hasil pengujian sistem yang dikembangkan dengan fuzzy, jaringan syaraf tiruan, pohon keputusan, dan pakar diperoleh nilai akurasi sebesar 91,96\%. Elshawi, Al-Mallah, dan Sakr [24] memprediksi hipertensi menggunakan model berbasis machine learning. Output dari learning machine adalah klasifikasi hipertensi tinggi, sedang, dan rendah.

Tengnah, Sooklall, dan Nagowah [25] membangun model untuk diagnosis hipertensi menggunakan pembelajaran mesin. Hasil pengujian dengan membandingkan data latih dan data dengan berbagai model diperoleh nilai akurasi sebesar 98,7\%. Penelitian Chang et al. [26] menggunakan XGBoost Pembelajaran Mesin. Sistem yang dikembangkan memiliki akurasi $94 \%$. Shiraz H.E [27] menggunakan logika fuzzy untuk meningkatkan klasifikasi dalam diagnosis hipertensi. Penerapan logika pada klasifikasi dapat meningkatkan akurasi sebesar 4,6\% dengan nilai akurasi sebesar 94,6\%. Nour, dan Polat [28] mengembangkan sistem otomatisasi untuk klasifikasi jenis Hipertensi menggunakan fitur pribadi dengan pembelajaran mesin. Hasil perbandingan metode klasifikasi, sistem yang diusulkan memiliki akurasi yang lebih baik dengan akurasi 97\%. Ambika, Raghuraman dan SaiRamesh [29] menggunakan algoritma Support Vector Machine (SVM). Sistem yang dikembangkan memiliki tingkat akurasi sebesar 91,8\%. Chatrati et al [30] mengembangkan rumah pintar untuk memantau dan memprediksi diabetes dan hipertensi dari tekanan darah dan glukosa darah menggunakan SVM dan metode klasifikasi lainnya. Hasil perbandingan metode menunjukkan bahwa metode SVM memiliki tingkat akurasi yang paling baik. Peneliti utama sebagai referensi penelitian ini diambil dari Lopez-Martínez [31] dengan algoritma Artificial Neural Network (ANN). Hasil performansi sistem menunjukkan akurasi sebesar 73,2\%. Berdasarkan beberapa penelitian yang telah dilakukan dengan variabel dan algoritma yang berbeda seperti fuzzy, algoritma genetika, pohon keputusan, c4.5, machine learning, dan Support Vector Machine (SVM) memiliki akurasi yang berbeda, namun penerapan metode pembobotan gabungan dengan metode Profile Matching untuk diagnosis risiko hipertensi belum ditemukan. Penggunaan metode Profile Matching mampu menghitung variabel yang memiliki pengaruh dan variabel yang kurang berpengaruh terhadap risiko hipertensi, maka metode ini tepat untuk mengklasifikasikan risiko hipertensi..

\section{Metode}

\subsection{Model Klasifikasi}

Klasifikasi adalah pengelompokan berdasarkan ketentuan atau standar yang dimiliki sehingga lebih mudah untuk mengenali sesuatu [32]. Konsep klasifikasi digunakan untuk menentukan risiko hipertensi menggunakan metode rule-based weighting dan profile matching. Model klasifikasi ditunjukkan pada Gambar 1.



\subsection{Profile Matching}

Profile Matching merupakan mekanisme dalam menentukan keputusan dengan asumsi bahwa ada tingkat ideal variabel prediktor yang harus dipenuhi [33]. Metode ini digunakan untuk mengetahui profil risiko hipertensi dan bukan hipertensi berdasarkan variabel. Pengelompokan variabel dibagi menjadi 2 (dua) yaitu faktor inti (CF) dan faktor sekunder (SF) dengan menggunakan persamaan berikut:

$$
C F=\frac{\sum C F}{\sum I C} \quad S F=\frac{\sum S F}{\sum I S}
$$

Keterangan:

$\mathrm{CF}=$ Core factor, $\mathrm{SF}=$ Secondary factor. $\mathrm{IC}=$ Jumlah variabel faktor inti, IS= Jumlah variabel faktor sekunder. Nilai yang dihitung untuk CF dan SF kemudian dihitung untuk nilai total untuk klasifikasi menggunakan persamaan berikut:

$$
\text { Kelas }=(x) \% . C F+(x) \% . S F
$$

\subsection{Model Usulan}

Model yang diusulkan menggunakan pendekatan pembobotan berbasis aturan yang dikombinasikan dengan metode Profile Matching. Pembobotan berbasis aturan menggunakan fungsi IF-then untuk menghitung bobot risiko hipertensi untuk setiap variabel. Metode profile matching digunakan untuk menghitung faktor inti dan faktor sekunder untuk klasifikasi risiko. Model dikembangkan dengan menggambarkan arsitektur prototipe yang diusulkan pada Gambar 2 . 


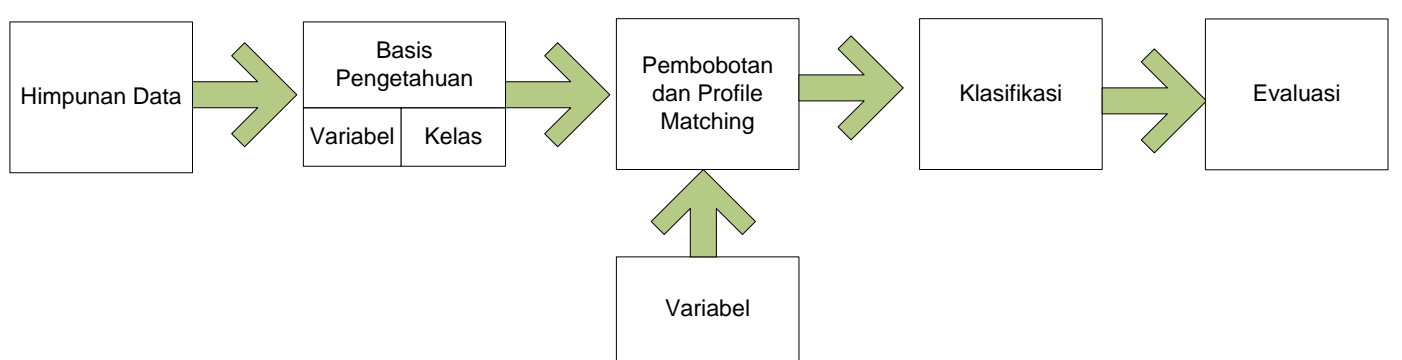

\subsection{Himpunan Data}

Kumpulan data yang digunakan dari NHANES pada 2015-2016. Dataset ini ditujukan untuk akses publik dan pemanfaatan layanan kesehatan. Kumpulan data ini disiapkan dan diterbitkan melalui Pusat Pengendalian dan Pencegahan Penyakit (CDC) untuk memberikan akses penuh. Kumpulan data asli terdiri dari lima folder dari 2007 hingga 2016, masing-masing berisi file pdf dengan statistik tingkat respons survei NHANES dan file SAS Transport untuk semua variabel pengukuran survei [31]

\subsection{Basis Pengetahuan}

\subsubsection{Variabel}

Variabel diambil dari Pima Indian Hipertensi Data (PIDD) dari UCI Machine Learning Repository [31]. Berdasarkan dataset, terdapat 7 (tujuh) variabel yang digunakan untuk mengklasifikasikan risiko hipertensi. Variabel ditunjukkan pada Tabel 2

Table 2. Input variabel untuk menentukan risiko hipertensi

\begin{tabular}{ccccccc}
\hline v1 & v2 & v3 & v4 & v5 & v6 & v7 \\
\hline Kelamin & Usia & Ras & BMI & Ginjal & Merokok & Diabetes \\
Pria/Wanita & Tahun & - & Kg/m2 & Ya/Tidak & Ya/Tidak & Ya/Tidak \\
\hline
\end{tabular}

Variabel gender berdasarkan status pasien. Umur dihitung berdasarkan tahun lahir. Ras dikaitkan dengan ciri fisik, seperti tekstur rambut atau warna kulit. BMI (Body Mass Index) adalah metrik standar yang digunakan dalam kelas berat badan. Ginjal adalah informasi yang berisi tentang kondisi pasien yang memiliki riwayat penyakit ginjal. Gagal ginjal akut adalah istilah untuk suatu kondisi dimana ginjal seseorang mengalami kerusakan secara tiba-tiba, sehingga tidak dapat berfungsi. Biasanya, gagal ginjal akut terjadi sebagai komplikasi dari penyakit serius lainnya. Asap merupakan informasi dari variabel bahwa pasien adalah perokok atau bukan. Diabetes adalah data riwayat pasien yang menderita diabetes.

\subsubsection{Pembobotan Berbasis Aturan}

Perhitungan bobot berdasarkan aturan untuk mendapatkan bobot kelas hipertensi dan non-hipertensi. Perhitungan pembobotan menggunakan fungsi IF-then yang ditunjukkan pada Algoritma 1

Algoritma 1. Contoh pembobotan untuk variabel kelamin

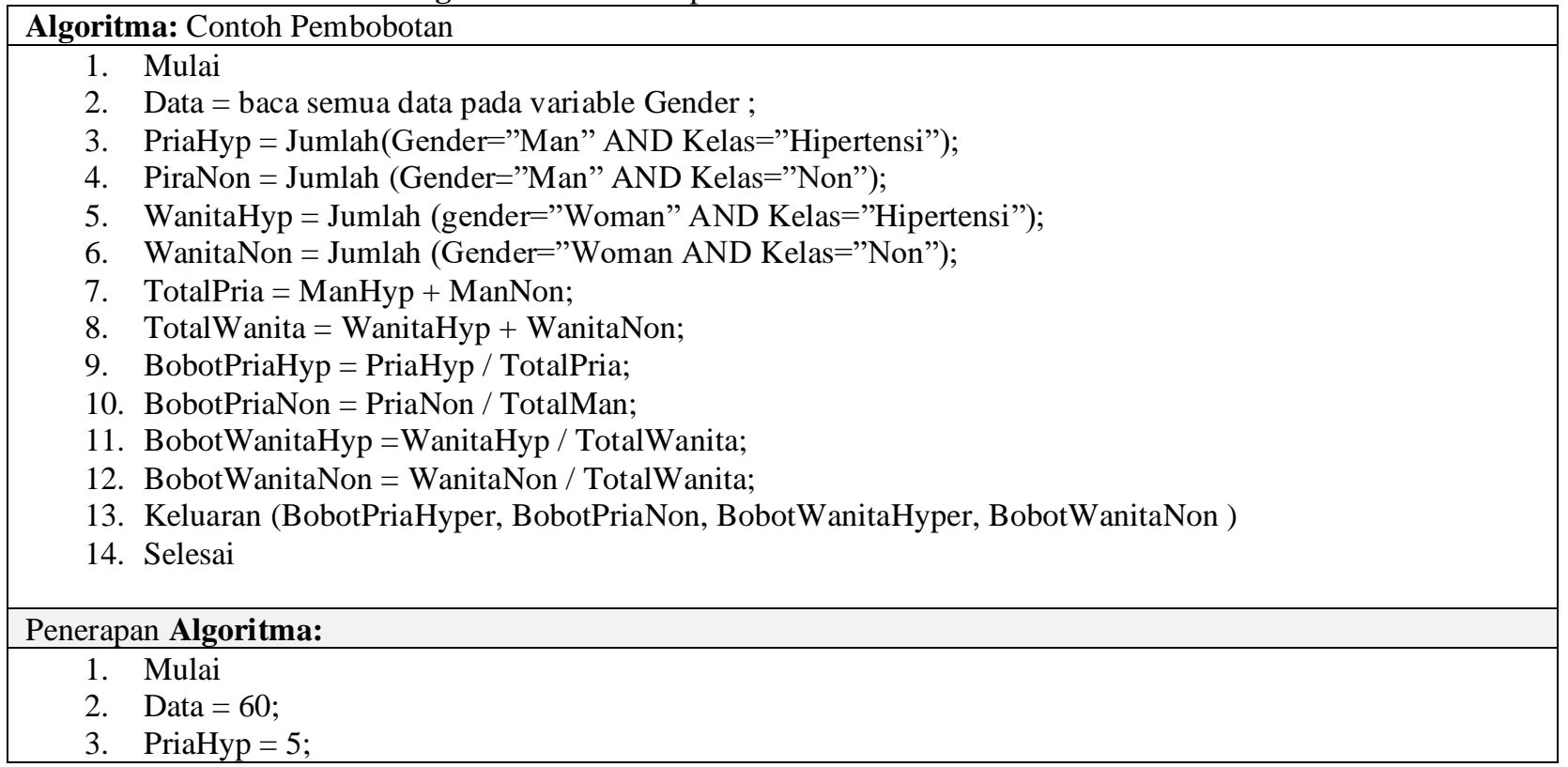




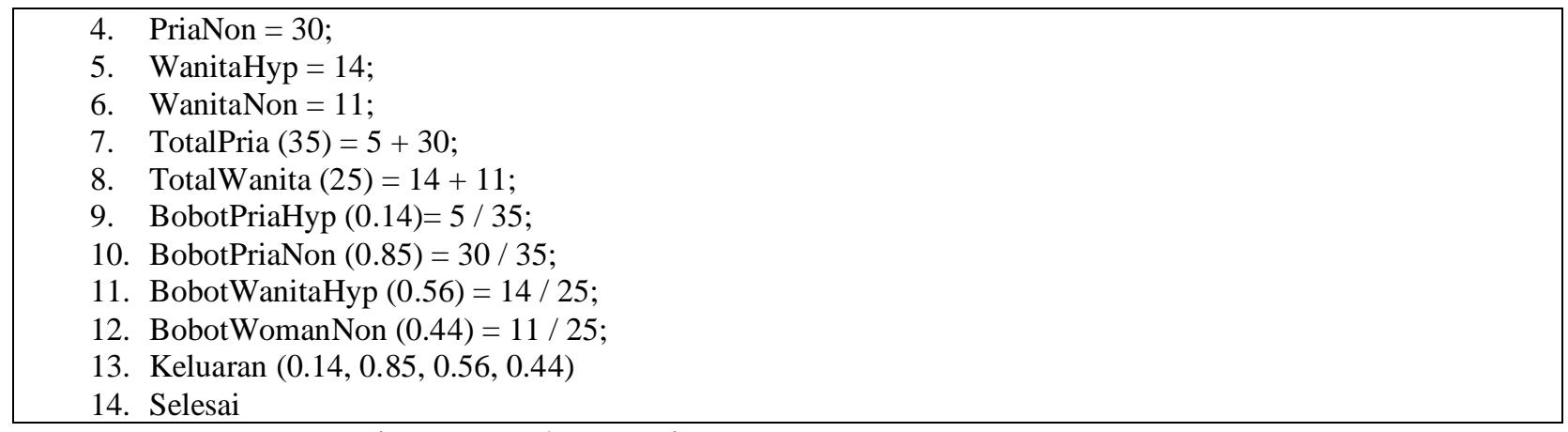

Keterangan: Hyp=Hypertensi, Non=Non-hypertensi

Perhitungan bobot masing-masing variabel untuk kelas hipertensi dan non-hipertensi dilakukan untuk variabel lain seperti Umur, Ras, IMT, Ginjal, Asap, dan Diabetes.
Perhitungan pembobotan untuk masing-masing kelas ditunjukkan pada Tabel 3.

Tabel 3. Pembobotan berbasis aturan untuk setiap kelas

\begin{tabular}{|c|c|c|c|c|}
\hline Kelas & Kelamin & Usia & Ras & BMI \\
\hline Hipertensi & $\begin{array}{l}\text { If Gender="Man" } \\
\text { Then Hyp=0.14; } \\
\text { If Gender="Woman" } \\
\text { Then Hyp=0.56; }\end{array}$ & $\begin{array}{l}\text { If (Age>70) Then } \\
\text { Hyp=0.9; } \\
\text { Else If } \\
(\text { Age }>66) \text { Then } \\
\text { Hyp=0.92; } \\
\text { Else If } \\
\text { (Age }>55) \text { Then } \\
\text { Hyp=0.58, } \\
\text { Else If } \\
\text { (Age }>40) \text { Then } \\
\text { Hyp=0.51; } \\
\text { Else If } \\
(\text { Age }>30) \text { Then } \\
\text { Hyp=0.36; } \\
\text { Else } \\
\text { Hyp=0.1 }\end{array}$ & $\begin{array}{l}\text { If Race="Putih" Then } \\
\text { Hyp=0.28; Else If } \\
\text { Race="Meksiko" Then } \\
\text { Hyp=0.5; } \\
\text { Else If Race="Hitam" } \\
\text { Then Hyp=0.35; } \\
\text { Else If } \\
\text { Race="Hispanik" Then } \\
\text { Hyp=0.14; } \\
\text { Else If Race="Other" } \\
\text { Then Hyp=0; } \\
\text { Else If } \\
\text { Race="America" Then } \\
\text { Hyp=0; }\end{array}$ & $\begin{array}{l}\text { If BMI }>31 \text { Then } \\
\text { Hyp }=1, \\
\text { Else If } \\
\text { BMI }>30 \text { Then } \\
\text { Hyp }=0.39, \\
\text { Else If } \\
\text { BMI }>25 \text { Then } \\
\text { Hyp=0.25, } \\
\text { Else Hyp=0.42 }\end{array}$ \\
\hline Non & $\begin{array}{l}\text { If Gender="Man" } \\
\text { Then Non=0.86; } \\
\text { If Gender="Woman" } \\
\text { Then Non=0.52; }\end{array}$ & $\begin{array}{l}\text { If }(\text { Age }>70) \text { Then } \\
\text { Non }=0.1, \\
\text { Else If }(\text { Age }>66) \\
\text { Then Non=0, } \\
\text { Else If }(\text { Age }>55) \\
\text { Then Non }=0.08, \text { Else } \\
\text { If }(\text { Age }>40) \text { Then } \\
\text { Non=0.51, } \\
\text { Else If }(\text { Age }>30) \\
\text { Then Non }=0.64 ; \\
\text { Else Non }=0.9 ;\end{array}$ & $\begin{array}{l}\text { If Race="Putih" Then } \\
\text { Non=0.72, Else If } \\
\text { Race="Mexico" Then } \\
\text { Non=0.5, } \\
\text { Else If Race="Hitam" } \\
\text { Then Non=0.5, } \\
\text { Else If Race=" } \\
\text { Hispanic" Then } \\
\text { Non=0.86, Else If } \\
\text { Race=" Other" Then } \\
\text { Non=1, Else If Race=" } \\
\text { America" Then Non=1, }\end{array}$ & $\begin{array}{l}\text { If } \mathrm{BMI}>31 \text { Then } \\
\text { Non=0, } \\
\text { Else If } \\
\text { BMI }>30 \text { Then } \\
\text { Non=0.61, } \\
\text { Else If } \\
\text { BMI }>25 \text { Then } \\
\text { Non=0.75, Else } \\
\text { Non=0.58; }\end{array}$ \\
\hline
\end{tabular}

\begin{tabular}{|c|c|c|c|c|}
\hline Kelas & Ginja & \multicolumn{2}{|l|}{ Merokok } & Diabetes \\
\hline \multirow[t]{4}{*}{ Hipertensi } & If Ginjal="Ya" Then Hyp=1, & Merokok="Ya" & Then & Diabetes="Ya" \\
\hline & Else If Ginjal="No" Then & Нyр $=0.37, \quad$ Else & & Hyp $=0.8$, Else If Diabetes="No" \\
\hline & Нyр $=0.29$ & Merokok="No" & Then & Then Нyp=0.27; \\
\hline & & Нyр $=0.26$ & & \\
\hline \multirow[t]{4}{*}{ Non } & If Ginjal="Ya" Then Non=0, & Merokok="Ya" & Then & Diabetes="Ya" \\
\hline & Else If Ginjal="No" Then & Non $=0.63, \quad$ Else & & Non $=0.2$, Else If Diabetes $=" N o "$ \\
\hline & Нур $=0.71$ & Merokok="No" & Then & Then Non=0.73; \\
\hline & & Non=0.74; & & \\
\hline
\end{tabular}


Keterangan : Hyp = Hipertensi, Non=Non-Hipertensi

Pembobotan pasien untuk ID="93610", Jenis Kelamin="Laki-Laki", Usia=51, Ras=Hispanik, BMI=25, Ginjal=Tidak, Asap=Ya, dan Diabetes=Tidak.

Berdasarkan data tersebut, kemudian dihitung nilai bobot untuk masing-masing variabel yang ditunjukkan pada Tabel 4

Tabel 4. Pembobotan untuk hipertensi, dan non-kelas

\begin{tabular}{cccccccc}
\hline No & Kelamin & Usia & Ras & BMI & Ginjal & Merokok & Diabetes \\
\hline 93610 & Pria & 51 & Hispanic & 25 & No & Ya & No \\
\hline Kelas & & \multicolumn{7}{c}{ Nilai } \\
\hline Hipertensi & 0.14 & 0.51 & 0.14 & 0.25 & 0.29 & 0.37 & 0.27 \\
Non & 0.86 & 0.49 & 0.86 & 0.75 & 0.71 & 0.63 & 0.73 \\
\hline
\end{tabular}

\subsection{Penerapan Metode Profile Matching}

3.6.1 Core Factor (CF) and Secondary Factor (SF)

Faktor inti adalah kelompok parameter utama. Sedangkan faktor sekunder merupakan kelompok parameter yang tidak mempunyai pengaruh kuat terhadap hasil diagnosis risiko hipertensi. Pengelompokan variabel $\mathrm{CF}$ dan SF berdasarkan perhitungan menggunakan algoritma Decision Tree. Variabel yang dibagi menjadi faktor inti dan faktor sekunder ditunjukkan pada Tabel 5.
Tabel 5. Variable core factor (CF) dan secondary factor (SF)

\begin{tabular}{lll}
\hline & Core Factor & \multicolumn{1}{c}{ Secondary Factor } \\
\hline 1. Usia & 1. Jenis Kelamin \\
2. BMI & 2. Ras \\
3. Diabetes & 3. Ginjal \\
& 4. Merokok
\end{tabular}

Tahap selanjutnya melakukan perhitungan untuk mendapatkan nilai rata-rata $\mathrm{CF}$ dan SF. Perhitungan nilai rata-rata ditunjukkan pada Tabel 6-7

Tabel 6. Rata-rata nilai CF dan SF untuk kelas hipertensi

\begin{tabular}{ll}
\hline \multicolumn{1}{c}{ Nilai Core Factor } & \multicolumn{1}{c}{ Nilai Secondary Factor } \\
\hline$C F=\frac{\sum C F}{\sum I C}$ & $S F=\frac{\sum S F}{\sum I S}$ \\
$C F=\frac{(0.51+0.25+0.27)}{(3)}=0.343$ & $S F=\frac{(0.14+0.14+0.29+0.37)}{(4)}=0.235$ \\
\hline
\end{tabular}

Table 7. Rata-rata nilai CF dan SF untuk kelas non-hipertensi

\begin{tabular}{ll}
\hline \multicolumn{1}{c}{ Nilai Core Factor } & \multicolumn{1}{c}{ Nilai Secondary Factor } \\
\hline$C F=\frac{\sum C F}{\sum I C}$ & $S F=\frac{\sum S F}{\sum I S}$ \\
$C F=\frac{(0.49+0.75+0.73)}{(3)}=0.650$ & $S F=\frac{(0.86+0.86+0.71+0.63)}{(4)}=0.690$
\end{tabular}

\subsection{Klasifikasi Risiko Hipertensi}

Penentuan klasifikasi risiko hipertensi dilakukan dengan menghitung masing-masing kelas untuk kelas hipertensi dan non-hipertensi. Perhitungan dilakukan dari bobot variabel $\mathrm{CF}$ sebesar $60 \%$ dan bobot variabel SF sebesar $40 \%$. Perhitungan klasifikasi risiko hipertensi menggunakan persamaan berikut::

$$
\begin{aligned}
\text { Hipertensi } & =(60 * \mathrm{CF})+(40 * \mathrm{SF}) \\
& =(60 * 0.343)+(40 * 0.235) \\
& =20.58+9.4 \\
& =\mathbf{3 0 . 0 0} \\
& =(45 * \mathrm{CF})+(25 * \mathrm{SF}) \\
& =(38 * 0.650)+(23 * 0.690) \\
& =29.25+17.24 \\
& =\mathbf{4 2 . 4 9}
\end{aligned}
$$

Berdasarkan nilai total masing-masing kelas, kelas yang memiliki skor tertinggi menjadi keputusan dalam diagnosis.

\section{Pembahasan dan Hasil}

\subsection{Sistem Pakar}

Aplikasi yang dikembangkan menggunakan bahasa pemrograman Pascal dari Delphi IDE dengan Ms. Access. Tampilan halaman utama aplikasi ditunjukkan pada Gambar 2. Halaman utama digunakan untuk memanggil halaman lain yang memiliki 2 menu yaitu menu klasifikasi dan menu tutup. Menu klasifikasi memiliki submenu untuk memanggil halaman perhitungan klasifikasi dan menutup aplikasi memiliki submenu keluar yang digunakan untuk keluar dari aplikasi 


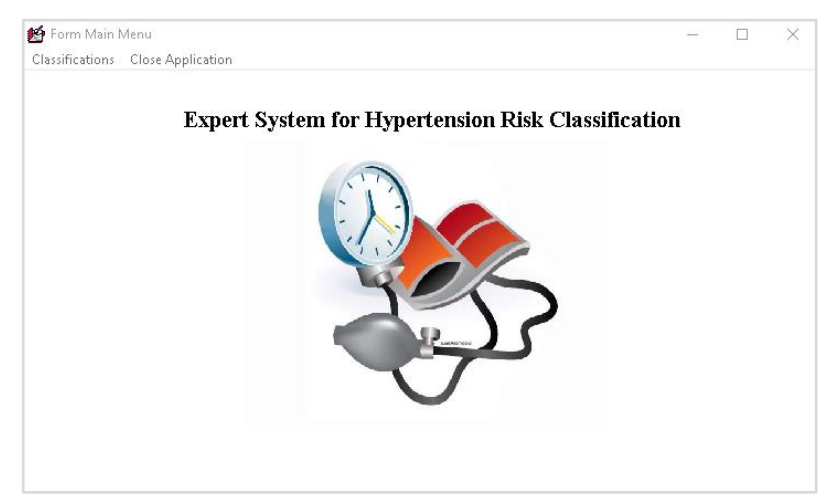

Gambar 3. Menu utama antarmuka pengguna Halaman perhitungan klasifikasi ditunjukkan pada Gambar 3. Pengguna dapat menginput data berdasarkan variabel pasien kemudian menekan tombol "klasifikasi" maka aplikasi akan menghitung nilai setiap kelas. Nilai kelas yang lebih tinggi adalah hasil dari keputusan risiko hipertensi

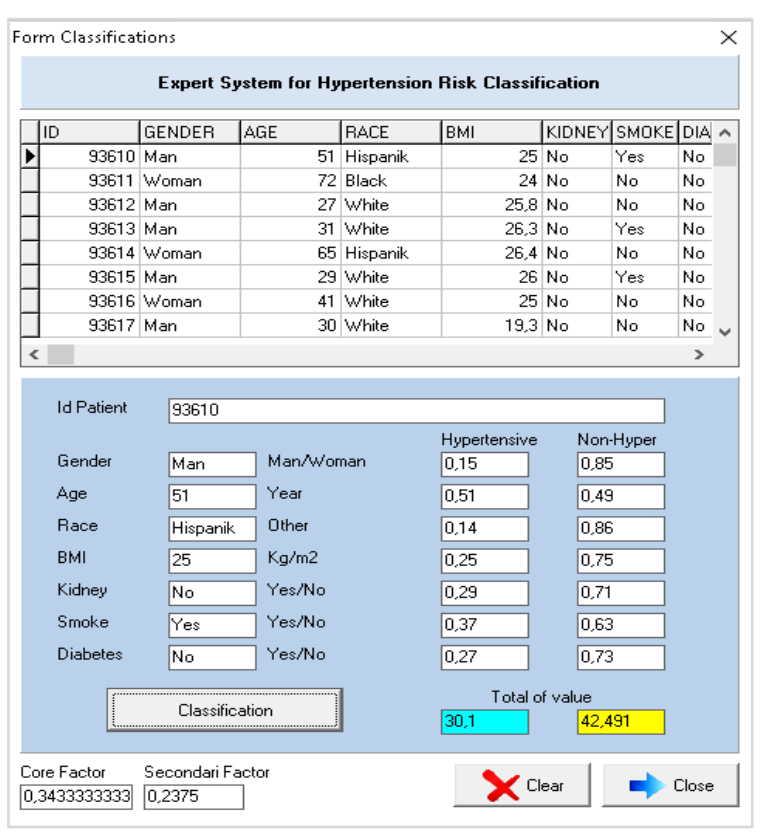

Gambar 4. Risiko klasifikasi antarmuka pengguna

Berdasarkan hasil perhitungan dari pasien "ID = 93610" dengan variabel jenis kelamin = "laki-laki", umur = 51, ras = "Hispanik", BMI = 25, ginjal = "Tidak", Asap = "Ya" dan diabetes $=$ "Tidak" maka diprediksi tidak memiliki risiko tinggi terkena hipertensi. Hasil klasifikasi lengkap ditunjukkan pada Tabel 8

Table 8. Hasil klasifikasi risiko hipertensi

\begin{tabular}{|c|c|c|c|c|c|c|c|c|c|c|}
\hline \multirow[b]{2}{*}{ No } & \multirow[b]{2}{*}{ Kelamin } & \multirow[b]{2}{*}{ Usia } & \multirow[b]{2}{*}{ Ras } & \multirow[b]{2}{*}{ BMI } & \multirow[b]{2}{*}{ Ginjal } & \multirow[b]{2}{*}{ Merokok } & \multirow[b]{2}{*}{ Diabetes } & \multicolumn{2}{|c|}{ Kelas } & \multirow[b]{2}{*}{ Sukses } \\
\hline & & & & & & & & Dataset & $\begin{array}{l}\text { Sistem } \\
\text { Usulan } \\
\end{array}$ & \\
\hline 1 & Pria & 51 & Hispanic & 25 & Tidak & $\mathrm{Ya}$ & Tidak & Non & Non & Ya \\
\hline 2 & Wanita & 72 & Hitam & 24 & Tidak & Tidak & Tidak & Hipertensi & Hipertensi & $\mathrm{Ya}$ \\
\hline 3 & Pria & 27 & Putih & 25,8 & Tidak & Tidak & Tidak & Non & Non & Ya \\
\hline 4 & Pria & 31 & Putih & 26,3 & Tidak & $\mathrm{Ya}$ & Tidak & Non & Non & $\mathrm{Ya}$ \\
\hline 5 & Wanita & 65 & Hispanic & 26,4 & Tidak & Tidak & Tidak & Non & Non & Ya \\
\hline 6 & Pria & 29 & Putih & 26 & Tidak & $\mathrm{Ya}$ & Tidak & Non & Non & $\mathrm{Ya}$ \\
\hline 7 & Wanita & 41 & Putih & 25 & Tidak & Tidak & Tidak & Non & Non & Ya \\
\hline 8 & Pria & 30 & Putih & 19,3 & Tidak & Tidak & Tidak & Non & Non & $\mathrm{Ya}$ \\
\hline 9 & Pria & 29 & Putih & 28 & Tidak & $\mathrm{Ya}$ & Tidak & Non & Hipertensi & Tidak \\
\hline 10 & Pria & 50 & Putih & 26,2 & Tidak & Tidak & Tidak & Non & Non & $\mathrm{Ya}$ \\
\hline 11 & Pria & 28 & Hitam & 22,8 & Tidak & $\mathrm{Ya}$ & Tidak & Non & Non & $\mathrm{Ya}$ \\
\hline 12 & Wanita & 61 & Hitam & 30 & Tidak & Tidak & Tidak & Hipertensi & Hipertensi & $\mathrm{Ya}$ \\
\hline 13 & Wanita & 27 & Hitam & 26 & Tidak & Tidak & Tidak & Non & Non & Ya \\
\hline 14 & Pria & 60 & Hispanic & 25 & Tidak & Tidak & Tidak & Non & Non & $\mathrm{Ya}$ \\
\hline 15 & Pria & 40 & Putih & 19 & Tidak & $\mathrm{Ya}$ & Tidak & Non & Non & Ya \\
\hline 16 & Wanita & 70 & Mexico & 24 & Tidak & Tidak & Tidak & Hipertensi & Hipertensi & Ya \\
\hline 17 & Pria & 77 & Putih & 23,8 & $\mathrm{Ya}$ & $\mathrm{Ya}$ & $\mathrm{Ya}$ & Hipertensi & Hipertensi & Ya \\
\hline 18 & Wanita & 74 & Putih & 29 & Tidak & $\mathrm{Ya}$ & Tidak & Hipertensi & Hipertensi & $\mathrm{Ya}$ \\
\hline 19 & Wanita & 68 & Hitam & 24,6 & Tidak & Ya & Tidak & Hipertensi & Hipertensi & Ya \\
\hline 20 & Wanita & 39 & Hitam & 25 & Tidak & Tidak & Tidak & Non & Non & Ya \\
\hline
\end{tabular}




\begin{tabular}{|c|c|c|c|c|c|c|c|c|c|c|}
\hline 21 & Pria & 36 & Putih & 30 & Tidak & Ya & Tidak & Non & Non & Ya \\
\hline 22 & Pria & 65 & Hitam & 30,2 & Tidak & $\mathrm{Ya}$ & Tidak & Non & Non & $\mathrm{Ya}$ \\
\hline 23 & Pria & 60 & Putih & 19 & Tidak & $\mathrm{Ya}$ & No & Non & Non & $\mathrm{Ya}$ \\
\hline 24 & Pria & 55 & Mexico & 22 & Tidak & $\mathrm{Ya}$ & Ya & Hipertensi & Hipertensi & $\mathrm{Ya}$ \\
\hline 25 & Wanita & 44 & Hispanic & 32 & Tidak & Tidak & Tidak & Hipertensi & Hipertensi & $\mathrm{Ya}$ \\
\hline 26 & Pria & 56 & Putih & 25,9 & Tidak & $\mathrm{Ya}$ & Tidak & Non & Non & $\mathrm{Ya}$ \\
\hline 27 & Pria & 30 & Hispanic & 26,2 & Tidak & Tidak & Tidak & Non & Non & Ya \\
\hline 28 & Pria & 28 & Putih & 18,6 & Tidak & Tidak & Tidak & Non & Non & $\mathrm{Ya}$ \\
\hline 29 & Pria & 60 & Mexico & 25,2 & Tidak & Ya & Tidak & Non & Non & $\mathrm{Ya}$ \\
\hline 30 & Pria & 29 & Mexico & 19 & Tidak & Ya & Tidak & Non & Non & $\mathrm{Ya}$ \\
\hline 31 & Pria & 58 & Putih & 30,1 & Tidak & Tidak & Tidak & Non & Non & $\mathrm{Ya}$ \\
\hline 32 & Pria & 39 & Putih & 19 & Tidak & $\mathrm{Ya}$ & Tidak & Non & Non & Ya \\
\hline 33 & Wanita & 77 & Putih & 26,8 & Tidak & $\mathrm{Ya}$ & Tidak & Hipertensi & Hipertensi & $\mathrm{Ya}$ \\
\hline 34 & Wanita & 62 & Hitam & 24,9 & Tidak & $\mathrm{Ya}$ & Tidak & Hipertensi & Hipertensi & Ya \\
\hline 35 & Wanita & 32 & Hitam & 25 & Tidak & Tidak & Tidak & Non & Non & $\mathrm{Ya}$ \\
\hline 36 & Pria & 39 & Putih & 30 & Tidak & Ya & Tidak & Non & Non & $\mathrm{Ya}$ \\
\hline 37 & Pria & 55 & Putih & 18,5 & Tidak & $\mathrm{Ya}$ & Tidak & Non & Non & $\mathrm{Ya}$ \\
\hline 38 & Pria & 57 & Mexico & 25 & Tidak & Tidak & Ya & Non & Hipertensi & Tidak \\
\hline 39 & Pria & 60 & Mexico & 24,7 & Tidak & $\mathrm{Ya}$ & Ya & Hipertensi & Hipertensi & Ya \\
\hline 40 & Woman & 41 & Putih & 32 & Tidak & Tidak & Tidak & Hipertensi & Hipertensi & $\mathrm{Ya}$ \\
\hline 41 & Woman & 72 & Hitam & 24,6 & Tidak & $\mathrm{Ya}$ & Tidak & Hipertensi & Hipertensi & $\mathrm{Ya}$ \\
\hline 42 & Woman & 50 & Other & 18,4 & Tidak & Tidak & Tidak & Non & Non & $\mathrm{Ya}$ \\
\hline 43 & Man & 38 & Hitam & 30,2 & Tidak & Tidak & Tidak & Non & Non & $\mathrm{Ya}$ \\
\hline 44 & Woman & 70 & Mexico & 29,8 & Tidak & Tidak & Ya & Hipertensi & Hipertensi & Ya \\
\hline 45 & Man & 35 & Hispanic & 30,1 & Tidak & Tidak & Tidak & Non & Non & $\mathrm{Ya}$ \\
\hline 46 & Man & 30 & Other & 19 & Tidak & Tidak & Tidak & Non & Non & Ya \\
\hline 47 & Woman & 78 & Putih & 32 & $\mathrm{Ya}$ & $\mathrm{Ya}$ & Tidak & Hipertensi & Hipertensi & $\mathrm{Ya}$ \\
\hline 48 & Man & 36 & Putih & 25,3 & Tidak & $\mathrm{Ya}$ & Tidak & Non & Non & $\mathrm{Ya}$ \\
\hline 49 & Woman & 30 & Putih & 20,3 & Tidak & Tidak & Tidak & Non & Non & $\mathrm{Ya}$ \\
\hline 50 & Man & 76 & Hitam & 30,4 & Tidak & Tidak & Tidak & Hipertensi & Hipertensi & $\mathrm{Ya}$ \\
\hline 51 & Man & 46 & Putih & 30 & Tidak & $\mathrm{Ya}$ & Tidak & Non & Non & Ya \\
\hline 52 & Woman & 25 & Other & 19 & Tidak & Tidak & Tidak & Non & Non & $\mathrm{Ya}$ \\
\hline 53 & Woman & 56 & Hispanic & 30 & Tidak & Tidak & Tidak & Non & Non & $\mathrm{Ya}$ \\
\hline 54 & Man & 30 & Putih & 25 & Tidak & $\mathrm{Ya}$ & Tidak & Non & Non & $\mathrm{Ya}$ \\
\hline 55 & Woman & 28 & Putih & 18,6 & Tidak & Tidak & Tidak & Non & Non & $\mathrm{Ya}$ \\
\hline 56 & Woman & 53 & Putih & 24,9 & Tidak & $\mathrm{Ya}$ & Tidak & Hipertensi & Hipertensi & Ya \\
\hline 57 & Man & 27 & Putih & 19 & Tidak & $\mathrm{Ya}$ & Tidak & Non & Non & $\mathrm{Ya}$ \\
\hline 58 & Woman & 71 & Putih & 20 & Tidak & Tidak & Tidak & Hipertensi & Hipertensi & Ya \\
\hline 59 & Woman & 35 & Mexico & 26 & Tidak & Tidak & Tidak & Non & Non & $\mathrm{Ya}$ \\
\hline 60 & Man & 75 & America & 27 & Tidak & $\mathrm{Ya}$ & Tidak & Non & Non & $\mathrm{Ya}$ \\
\hline
\end{tabular}

Kid=Ginjal, Smo=Merokok, Dia=Diabetes. Sources: https://github.com/sysdevelopment/phd [31]

Berdasarkan hasil klasifikasi risiko pada Tabel 8, terdapat perbedaan jumlah klasifikasi untuk hipertensi dan jumlah non-hipertensi. Jumlah kelas yang direkomendasikan ditunjukkan dalam bentuk grafik pada Gambar 5 


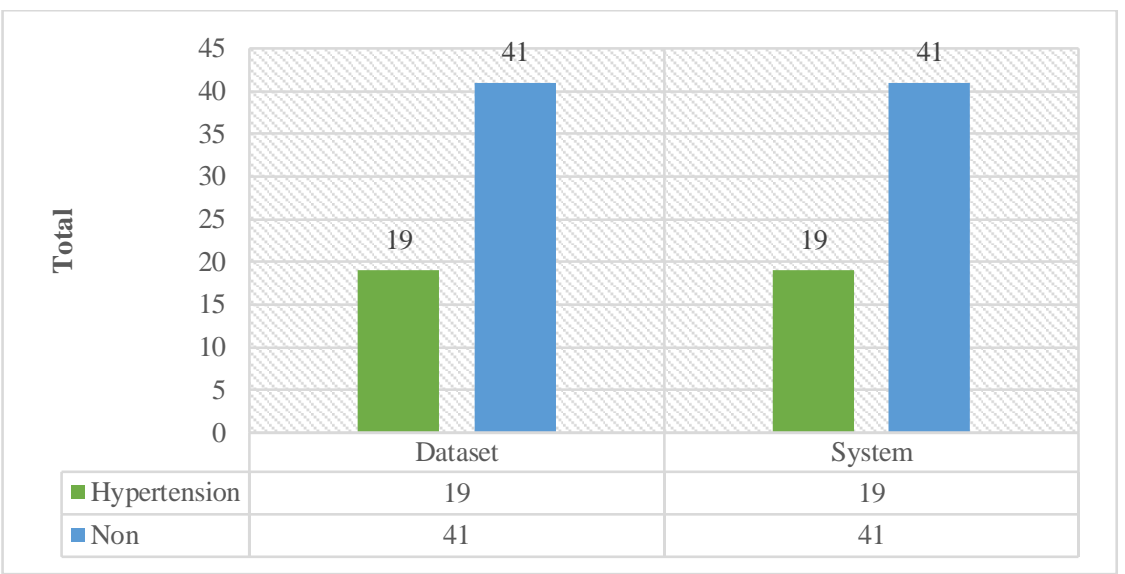

Gambar 5. Bagan perbandingan kelas

\subsection{Evaluations}

Untuk mengukur kinerja aplikasi yang diusulkan, perlu dilakukan perhitungan untuk mendapatkan nilai akurasi. Perhitungan ketelitian adalah pengukuran untuk mengetahui tingkat kedekatan besaran dengan nilai sebenarnya. Perhitungan akurasi menggunakan persamaan berikut:

Confidence Indicator $(C I)=\frac{\text { success number }}{\text { total number of test }} * 100$

Confidence Indicator $(C I)=\frac{58}{60} * 100=96.67 \%$

Hasil perhitungan confidence indicator (CI) menunjukkan bahwa metode yang diusulkan dapat mengklasifikasikan dengan benar sebanyak 58 dari 60 data. Selain confidence indicator (CI), juga dihitung dengan menggunakan confusion matrix pada Tabel 9 untuk mendapatkan nilai sensitivitas, spesifisitas, presisi, dan akurasi.

Tabel 9. Perbandingan nilai prediksi dan aktual

\begin{tabular}{|c|c|c|c|}
\hline \multirow{5}{*}{ 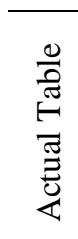 } & & 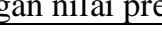 & \\
\hline & \multicolumn{3}{|c|}{ Prediction table } \\
\hline & Kelas & Hipertensi & $\begin{array}{c}\text { Non- } \\
\text { Hipertensi }\end{array}$ \\
\hline & Hipertensi & 18 & 1 \\
\hline & Non & 1 & 40 \\
\hline
\end{tabular}

Langkah selanjutnya adalah menghitung nilai akurasi, presisi, dan recall menggunakan variabel $: \mathrm{TP}=$ Benar positif, $\mathrm{FN}=$ Negatif salah, FP = Positif salah, $\mathrm{TN}=$ Benar negatif seperti Tabel 10.

Tabel 10. Variabel evaluasi

\begin{tabular}{lc}
\hline Evaluasi & Metode Usulan \\
\hline TP = True Positive & 58 \\
TN $=$ True Negative & 58 \\
FN = False Negative & 2 \\
FP = False Prositive & 2 \\
\hline
\end{tabular}

$$
\begin{aligned}
& \text { Sensitivity }=\frac{T P}{T P+F N}=\frac{58}{(58+2)}=96.67 \% \\
& \text { Specificity }=\frac{T N}{T N+F P}=\frac{58}{58+2}=96.14 \% \\
& \text { Precision }=\frac{T P}{T P+F P}=\frac{58}{58+2}=96.16 \% \\
& \text { Classification Accuracy }=\frac{T P+T N}{(T P+F P+T N+F N)} \\
& \qquad=\frac{(58+58)}{(58+2+58+2)}=96.67 \%
\end{aligned}
$$

Berdasarkan Tabel 9, nilai sensitivitas, spesifisitas, presisi, dan akurasi ditunjukkan pada Tabel 11.

Tabel 11. Sensitivity, specificity, precision, dan accuracy

\begin{tabular}{c|c|c|c}
\hline Sensitivity & Specificity & Precision & Accuracy \\
\hline $96.67 \%$ & 96.14 & 96.16 & $\mathbf{9 6 . 6 7}$ \\
\hline
\end{tabular}

\subsection{Perbandingan Sistem Usulan}

Metode usulan yang dikembangkan dibandingkan dengan metode klasifikasi lainnya menggunakan software
Rapid Miner Studio. Hasil pengujian menggunakan salah satu metode klasifikasi Decision Tree ditunjukkan pada Gambar 5. 

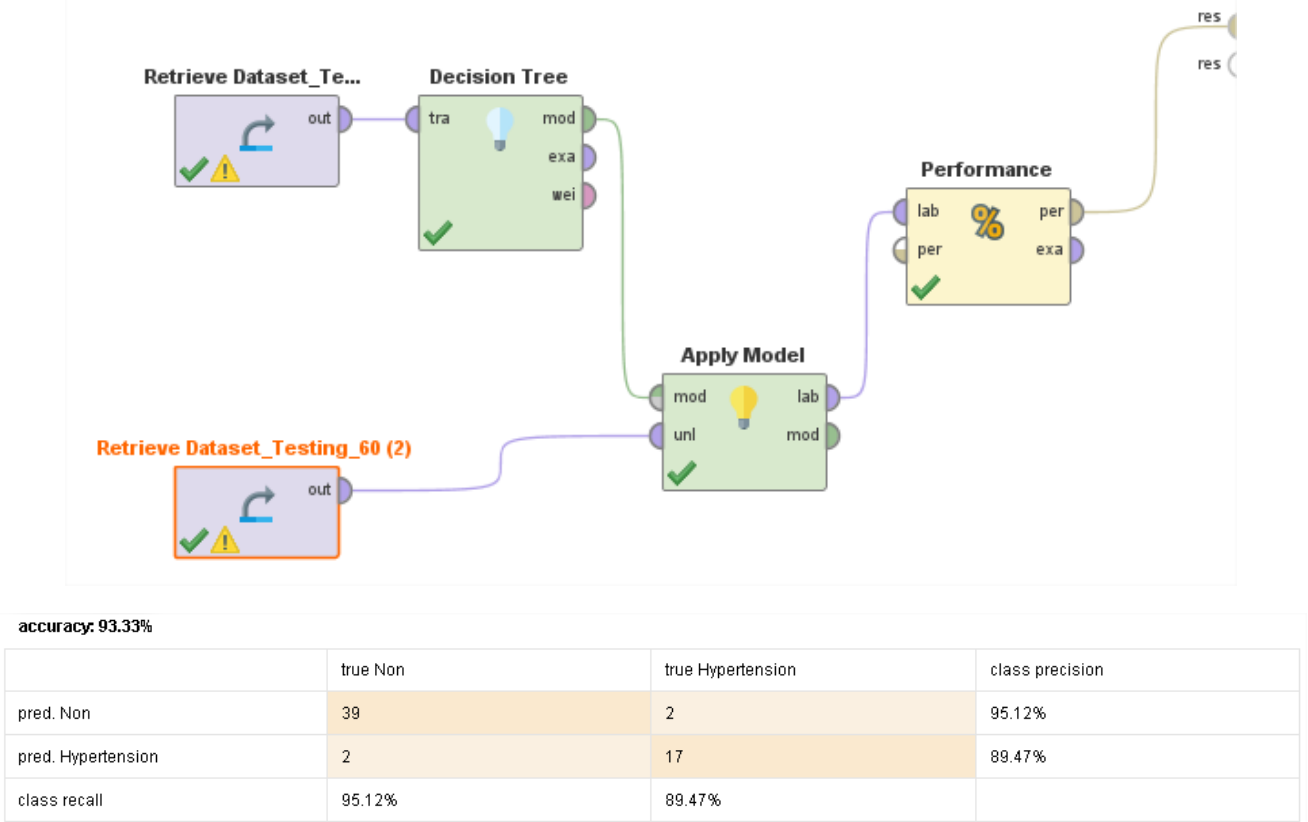

Gambar 6. Pohon keputusan algoritma akurasi

Selain pohon keputusan, uji akurasi dibandingkan dengan metode klasifikasi lain seperti pohon acak, tunggul keputusan, KNN, nave BaYa, pembelajaran mendalam, induksi aturan. Hasil perbandingan akurasi ditunjukkan pada Gambar 7..

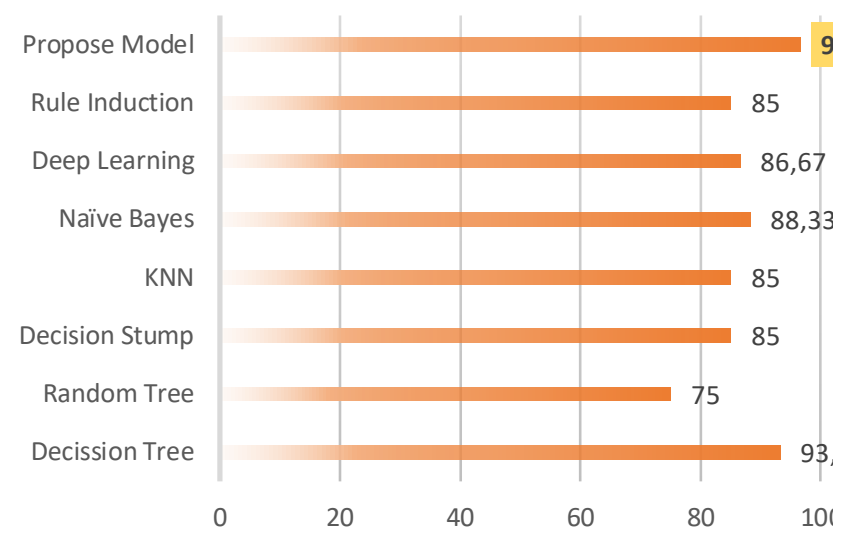

Gambar 7. Perbandingan akurasi algoritma klasifikasi

\section{Kesimpulan}

Penelitian ini menggunakan pendekatan yang berbeda untuk klasifikasi risiko hipertensi. Metode yang digunakan adalah rule-based weighting menggunakan fungsi IF-then yang dikombinasikan dengan metode profile matching. Pengujian sistem yang diusulkan menggunakan 60 (enam puluh) data uji dari Pima Indian Hipertensi Data dari UCI Machine Learning Repository. Pengujian dilakukan dengan membandingkan data pengujian dengan sistem yang diusulkan, nilai akurasinya adalah 96,67\%. Sistem yang diusulkan juga dibandingkan dengan metode klasifikasi lain seperti Decision Tree, Random Tree, Decision Stump, KNN, Naïve BaYa, Deep
Learning, dan Rule Induction. Hasil perbandingan menunjukkan bahwa sistem yang diusulkan memiliki tingkat akurasi yang lebih baik, sehingga dapat digunakan untuk mengklasifikasikan risiko untuk jenis penyakit lainnya..

\section{Data Sumber}

Kumpulan data yang digunakan dari NHANES pada 2015-2016. Dataset ini ditujukan untuk akses publik dan pemanfaatan layanan kesehatan. Kumpulan data ini disiapkan dan diterbitkan melalui Pusat Pengendalian dan Pencegahan Penyakit (CDC) untuk memberikan akses penuh. Kumpulan data asli terdiri dari lima folder dari 2007 hingga 2016, masing-masing berisi file pdf dengan statistik tingkat respons survei NHANES dan file SAS Transport untuk semua variabel pengukuran survei [31]

\section{Daftar Pustaka}

[1] B. Rumagit, J. Pojoh, and V. Manampiring, "Studi Deskriptif Pemberian Obat Pada Pasien Hipertensi Di Puskesmas Sario," J. Ilm. Farm. Poltekkes Manad., vol. 3, no. 2, 2012.

[2] A. J. Viera, L. W. Cohen, C. M. Mitchell, and P. D. Sloane, "High blood pressure knowledge among primary care patients with known Hipertensi: A North Carolina Family Medicine Research Network (NC-FMRN) study," J. Am. Board Fam. Med., vol. 21, no. 4, pp. 300-308, 2008, doi: 10.3122/jabfm.2008.04.070254.

[3] B. P. Medications and M. Changes, "Treatment of Hipertensi: JNC 8 and More," Res. Cent., vol. 3120, no. February, pp. 209-472, 2014, [Online]. Available: www.PharmacistsLetter.com\%5Cnwww.PrescribersLe tter.com\%5Cnwww.Pharmacy TechniciansLetter.com.

[4] Pusdatin, Hipertensi, Second., no. Hari Hipertensi Sedunia. Jakarta Selatan: Kementerian RI, 2014.

[5] Global Road Safety Facility \& IHME, "The Global Burden of Disease from Motorized Road Transport," World Bank Inst. Heal. Metrics Eval., p. 39, 2014, [Online]. 
http://documents.worldbank.org/curated/en/984261468 327002120/pdf/863040IHME0T4H0ORLD0BANK0c ompressed.pdf.

[6] J. R. Banegas et al., "High prevalence of masked uncontrolled Hipertensi in people with treated Hipertensi," Eur. Heart J., vol. 35, no. 46, pp. 3304 3312, 2014, doi: 10.1093/eurheartj/ehu016.

[7] H. Soetanto, S. Hartati, R. Wardoyo, and S. Wibowo, "Hipertensi drug suitability evaluation based on patient condition with improved profile matching," Indones. $J$. Electr. Eng. Comput. Sci., 2018, doi: 10.11591/ijeecs.v11.i2.pp453-461.

[8] A. A. Abdullah, Z. Zakaria, and N. F. Mohammad, "Design and development of Fuzzy Expert System for diagnosis of Hipertensi," Proc. - 2011 2nd Int. Conf. Intell. Syst. Model. Simulation, ISMS 2011, no. February 2017, pp. 113-117, 2011, doi: 10.1109/ISMS.2011.27.

[9] X. Y. Djam and Y. H. Kimbi, "Fuzzy Expert System for the Management of Hipertensi," Pacific J. Sci. Technol., vol. 12, no. 1, pp. 390-402, 2011, [Online]. Available: http://www.akamaiuniversity.us/PJST.htm.

[10] S. Das, P. K. Ghosh, and S. Kar, "Hipertensi diagnosis: A comparative study using fuzzy expert system and neuro fuzzy system," IEEE Int. Conf. Fuzzy Syst., no. 2005, 2013, doi: 10.1109/FUZZ-IEEE.2013.6622434.

[11] P. Srivastava, A. Srivastava, A. Burande, and A. Khandelwal, "A Note on Hipertensi Kelasification Scheme and Soft Computing Decision Making System," ISRN Biomath., vol. 2013, pp. 1-11, 2013, doi: $10.1155 / 2013 / 342970$.

[12] A. Kaur and A. Bhardwaj, "Genetic Neuro Fuzzy System for Hipertensi Diagnosis," Citeseer, vol. 5, no. 4, pp. 4986-4989, 2014, [Online]. Available: www.ijcsit.com.

[13] R. Kaur and A. Kaur, "Hipertensi Diagnosis Using Fuzzy Expert System," Int. J. Eng. Res. Appl., vol. 14, no. March, pp. 2248-9622, 2015, [Online]. Available: https://pdfs.semanticscholar.org/b7ad/d498b2927d356 40946c249158de32d33f21f.pdf.

[14] Z. Abrishami and H. Tabatabaee, "Design of A Fuzzy Expert System And A Multi-Layer Neural Network System For Diagnosis Of Hipertensi," Pharmacol. Life Sci. Bull. Env. Pharmacol. Life Sci, no. 11, pp. 138-145, 2015, [Online]. Available: https://pdfs.semanticscholar.org/0753/baef3fb0659fac0 26017a2c23a2752c55f04.pdf.

[15] J. C. Guzmán, P. Melin, and G. Prado-Arechiga, "A proposal of a fuzzy system for Hipertensi diagnosis," Adv. Intell. Syst. Comput., vol. 401, pp. 341-350, 2016, doi: 10.1007/978-3-319-26211-6_29.

[16] I. P. Adebayo, "Idowu Peter Adebayo. Predictive Model for the Kelasification of Hipertensi Risk Using Decision Trees Algorithm," Am. J. Math. Comput. Model., vol. 2, no. 2, pp. 48-59, 2017, doi: 10.11648/j.ajmcm.20170202.12.

[17] J. C. Guzmán, P. Melin, and G. Prado-Arechiga, "Fuzzy optimized Kelasifier for the diagnosis of blood pressure using genetic algorithm," Stud. Comput. Intell., vol. 749, pp. 309-318, 2018, doi: 10.1007/978-3-31971008-2_23.

[18] I. Z. Jibril, J. Agajo, L. A. Ajao, J. G. Kolo, and O. C. Inalegwu, "Development of a Medical Expert System for Hypertensive Patients Diagnosis: A KnowledgeBased Rules," Adv. Electr. Telecommun. Eng., vol. 1, no. 1, pp. 39-47, 2018.

[19] I. Miramontes, G. Martínez, P. Melin, and G. PradoArechiga, "A hybrid intelligent system model for Hipertensi risk diagnosis," Adv. Intell. Syst. Comput., vol. 648, pp. 202-213, 2018, doi: 10.1007/978-3-31967137-6_22.

[20] W. Jie, P. Yan, R. Xiaoxiao, and Q. Yixuan, An expert system for diagnosis and treatment of Hipertensi based on ontology, vol. 952. Springer Singapore, 2018.

[21] P. Melin, I. Miramontes, and G. Prado-Arechiga, "A hybrid model based on modular neural networks and fuzzy systems for Kelasification of blood pressure and Hipertensi risk diagnosis," Expert Syst. Appl., vol. 107, pp. 146-164, 2018, doi: 10.1016/j.eswa.2018.04.023.

[22] P. Melin and G. Prado-Arechiga, "Neuro-fuzzy modular approaches for Kelasification of arterial Hipertensi with a method for the expert rules optimization," SpringerBriefs Appl. Sci. Technol., vol. 0 , no. 9783319611488, pp. 23-47, 2018, doi: 10.1007/978-3-319-61149-5_4.

[23] M. S. Hossain, Fatema-Tuj-Johora, and K. Andersson, "A belief rule based expert system to assess Hipertensi under uncertainty," J. Internet Serv. Inf. Secur., vol. 9, no. $4, \quad$ pp. $18-38, \quad 2019, \quad$ doi: 10.22667/JISIS.2019.11.30.018.

[24] R. Elshawi, M. H. Al-Mallah, and S. Sakr, "On the interpretability of machine learning-based model for predicting Hipertensi," BMC Med. Inform. Decis. Mak., vol. 19, no. 1, 2019, doi: 10.1186/s12911-019-0874-0.

[25] M. A. J. Tengnah, R. Sooklall, and S. D. Nagowah, A predictive model for Hipertensi diagnosis using machine learning techniques. Elsevier Inc., 2019.

[26] W. Chang et al., "A machine-learning-based prediction method for Hipertensi outcomes based on medical data," Diagnostics, vol. 9, no. 4, 2019, doi: 10.3390/diagnostics9040178.

[27] N. A. Shiraz H.E, "Using Fuzzy Logic to Enhance the Kelasification and Diagnosing of Hypertention," $J$. Theor. Appl. Inf. Technol., vol. 97, no. 20, pp. 24302440, 2019.

[28] M. Nour and K. Polat, "Automatic Kelasification of Hipertensi Types Based on Personal Features by Machine Learning Algorithms," Math. Probl. Eng., vol. 2020, pp. 1-14, 2020, doi: 10.1155/2020/2742781.

[29] M. Ambika, G. Raghuraman, and L. SaiRamesh, "Enhanced decision support system to predict and prevent Hipertensi using computational intelligence techniques," Soft Comput., vol. 24, no. 17, pp. 1329313304, 2020, doi: 10.1007/s00500-020-04743-9.

[30] S. P. Chatrati et al., "Smart home health monitoring system for predicting type 2 diabetes and Hipertensi," J. King Saud Univ. - Comput. Inf. Sci., no. xxxx, 2020, doi: 10.1016/j.jksuci.2020.01.010.

[31] F. López-Martínez, E. R. Núñez-Valdez, R. G. Crespo, and V. García-Díaz, "An artificial neural network approach for predicting Hipertensi using NHANES data," Sci. Rep., vol. 10, no. 1, pp. 1-14, 2020, doi: 10.1038/s41598-020-67640-z.

[32] B. Williams and S. Cremaschi, "Kelasification Models," Comput. Aided Chem. Eng., p. 5, 2020.

[33] A. Suhartanto, "Decision Support System untuk Penilaian Kinerja Guru dengan Metode Profile Matching," J. Komput. Terap., vol. 2, no. 2, pp. 149158, 2016. 